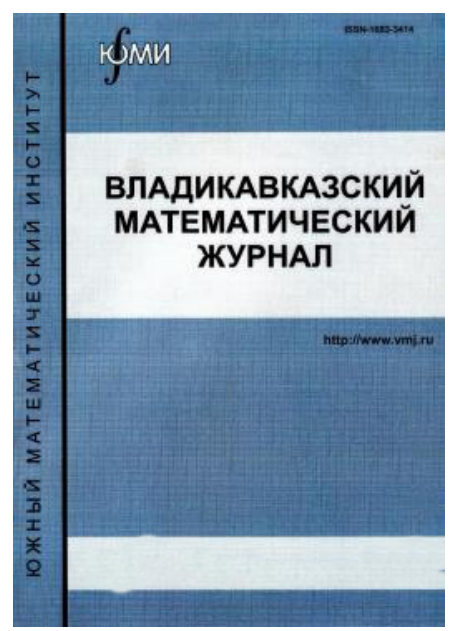

Гуров М.Н., Ногин В.А. $L_{p}-L_{q}$-оценки для обобщенных потенциалов Рисса с осциллирующими ядрами.

Получены $L_{p}-L_{q}$-оценки для обобщенных потенциалов Рисса с осциллирующими ядрами и однородными характеристиками, бесконечно диффреренцируемыми в $R^{\mathrm{n}} \backslash\{0\}$. Описаны выпуклые множества (1/p,1/q)плоскости, для точек которых упомянутые операторы ограничены из $L_{p}$ в $L_{q}$ и указаны области, где эти операторы не ограничены.

Гутнова А.К., Махнев А.А. Об автоморфизмах дистанционно регулярного графа с массивом пересечений $\{39,30,4 ; 1,5,36\}$.

В работе найдены возможные порядки и строение подграфов неподвижных точек автоморфизмов дистанционно регулярного графра с массивом пересечений $\{39,30,4 ; 1,5,36\}$.

Пасенчук А.Э. О расщеплении многочленов с коэффициентами из коммутативных банаховых алгебр.

Рассматривается задача о разложении многочленов с коэффициентами из унитальной коммутативной банаховой алгебры в произведение многочленов с коэффициентами из этой же алгебры. Указываются достаточные условия существования такого разложения и его конструкция, приводятся приложения в теории операторов Теплица на окружности и торе. В частности, для двумерного теплицева оператора со специальным символом произведена равносильная регуляризация.

Сива Кота Редди П., Пракаша К.Н., Сиддалингасвами В.М. Минимальная доминирующая энергия Рандича графра.

Для графра вводится понятие минимальной доминирующей энергии Рандича. Вычислены точные значения этой величины для некоторых графов. Кроме того, найдены верхняя и нижняя границы для минимальной доминирующей энергии Рандича.

Салимов Р.P. O степенном порядке роста нижних Q-гомеоморфизмов.

В работе исследуется асимптотическое поведение в точке нижних Q-гомеоморфизмов относительно p-модуля. Найдены достаточные условия на функцию $Q$, при которых отображение имеет степенной порядок роста. В работе приведены приложения этих результатов к классам Орлича - Соболева при условии типа Кальдерона на определенную функцию и, в частности, к классам Соболева. Приведен пример гомеоморфизма.

Шаповалова Л.Н. Уравнения Гаусса, Петерсона - Кодацци, Риччи в неголономных реперах.

В работе рассматривается изометрическое погружение $n$-мерного хаусдорфового ориентируемого многообразия, удовлетворяющего второй аксиоме счетности, в $m$-мерное полное односвязное риманово или псевдориманово пространство постоянной кривизны. С использованием неголономных реперов выводятся уравнения Гаусса, Петерсона - Кодацци, Риччи для погружений класса $C^{2} n$-мерного многообразия в m-мерное пространство. Основной результат получен с использованием обобщенного внешнего дифференцирования по де Раму. Показано, что при этом формы связности, погружения и кручения обладают непрерывным обобщенным внешним диффференциалом.

Шарапудинов И.И., Гаджиева 3.Д., Гаджимирзаев Р.М. Разностные уравнения и полиномы, ортогональные по Соболеву, порожденные многочленами Мейкснера.

Рассмотрен вопрос о представлении решения задачи Коши для разностного уравнения $r$-го порядка с переменными коэфффициентами и заданными начальными условиями путем разложения его решения в ряд Фурье по полиномам, ортогональным по Соболеву. Указанное представление базируется на конструировании новых полиномов, ортогональных по Соболеву и порожденных классическими полиномами Мейкснера. Для новых полиномов получена явная формула, содержащая многочлены Мейкснера. Этот результат позволяет исследовать асимптотические свойства сконструированных новых полиномов, ортогональных по Соболеву с заданным весом. Кроме того, это позволяет решить проблему, связанную с вычислением новых полиномов, сводя ее к применению известных рекуррентных соотношений для классических полиномов Мейкснера.

Коробейник Ю.Ф. О некоторых вопросах теории функций.

В заметке, посвященной памяти выдающегося российского математика А.Ф. Леонтьева, рассматриваются некоторые вопросы теории мероморфных и выпуклых функций. 


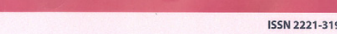 \\ ГЕОЛОгия И ЕОФИЗИКА IIA POCCK}

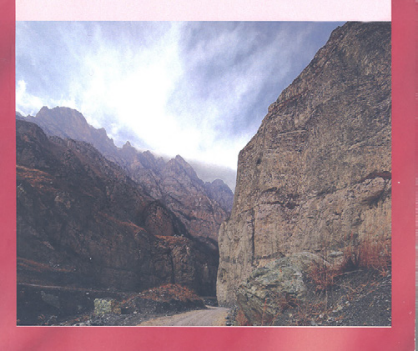

Богуш И.А., Шапошникова С.Д. Кобальт гидротермально-осадочных руд колчеданных месторождений Северного Кавказа.

В вулканогенной спилитово-кератофировой формации девона Северного Кавказа рассмотрена кобальтоносность двух вулканогенных свит кизилкольской и даутской. Аномальное содержание кобальта сосредоточено в массивных колчеданных рудах кизилкольской базальтовой свиты (D2 ks). Выделены поисковые критерии и типы кобальтоносных колчеданных руд. На примере кобальтового Худесского месторождения показано обогащение кобальтом пирита массивных серноколчеданных руд. Доказана локализация кобальта изоморфно входящего в полнокристаллический автобластический пирит. Определена перспективная кобальтоносность медноколчеданных гидротермальноосадочных месторождений Северного Кавказа.

Бурдзиева О.Г., Разоренов Ю.И., Дзеранов Б.В. Особенности мониторинга при подземной разработке старых месторождений.

Систематизированы сведения об управлении геомеханическим состоянием рудовмещающего массива в сложных горно-геологических условиях путем организации системы геомеханического мониторинга его напряженно-деформированного состояния геофизическими методами при подземной разработке скальных месторождений. Дан критический анализ теорий управления состоянием напряженно-деформированных скальных массивов. Приведены сведения о функциях, способах и схеме организации геофизического мониторинга подземных горных работ. Даны результаты использования геофизических методов на предприятиях - аналогах. Дан анализ геомеханических процессов при разработке старых месторождений Северного Кавказа и показаны особенности их разработки. Показано, что геофизический мониторинг добычных процессов позволяет оценивать устойчивость массива при различных условиях. Даны рекомендации по организации геофизического мониторинга при возобновлении добычных работ в зоне погашенного выработанного пространства.

Газеев В.М., Гурбанов А.Г., Лексин А.Б., Докучаев А.Я., Гурбанова О.А. Кельский вулканический район (Республика Южная Осетия): геохимические особенности пород и их геодинамическая интерпретация.

В юго-западной части восточного сегмента мегантиклинория Большого Кавказа расположены чет- вер- тичные вулканы Кельского вулканического района. Проведено петрографрическое и геохимическое изучение вулканитов, приведены результаты РФА, ICP-MS, INAA анализов и их обсуждение. Впервые показано, что породы обладают адакитоподобными характеристиками и по геохимическим параметрам они близки к вулканитам, формирующимся в субдукционных геодинамических обстановках (условиях). Сделано предположение, что геохимические особенности этого вулканизма следует связывать с «шолевой тектоникой» и с деформационными процессами, развивающимися при взаимодействии Черноморско-Закавказского микроконтинента с Большим Кавказом.

Исламов Д.А. Тепловые методы повышения нефтеотдачи миоценовых залежей Старогрозненского и Малгобек-Вознесенского месторожденuй.

Рассмотрены способы увеличения нефтеотдачи пластов для миоценовых залежей месторождений Чеченской Республики и Ингушетии с применением различных теплоносителей: паротепловое воздействие на Старогрозненском и Малгобек - Вознесенском месторождении, влажное внутрипластовое горение на Малгобек - Вознесенском месторождении. Выполнен анализ результатов проведенных работ и дана оценка возможных применений в других районах со сходными горно-геологическими условиями.

Конешов В.Н., Трифонова Т.А., Трифонов Д.В., Аракелян С.М. Взачмосвязь тектонических напряжений в земной коре и динамики функционирования бассейна подземных вод - возможное проявление в катастрофических наводнениях.

Обсуждается возможное влияние тектонических напряжений на возникновение катастрофических наводнений посредством механизма модификации 3D-сетей скальных формаций и транзита подземных вод в этой естественной транспортной системы в условиях функционирования водосборного бассейна реки. Считается, что несколько наводнений (не паводков) имевших место в 2013-2014 годы, вероятно, могли быть связаны с соответствующими сейсмическими процессами в земной коре. В практическом аспекте предлагаемая гипотеза может оказаться полезной при предварительном определении потенциально опасных районов, где могут происходить катастрофические события, связанные с водой, принимая во внимание влияния состояния подземной гидросферы и тектониче- 
ской структуры реологического участка земных недр на конкретных территориях.

Кюль Е.В. Тектонические оползневые массивы Центрального Кавказа.

В статье приводятся результаты инвентаризации основных тектонических оползневых массивов Центрального Кавказа. Вначале на основе проведенного тектонического районирования выделяются основные тектонические структуры исследуемой территории. При этом в пределах данных структур приводятся данные по скорости современных тектонических движений и сейсмической активности. Площадная оценка оползневой деятельности по основным административным районам субъектов-республик, а также основным речным бассейнам, проводится с учетом результатов тектонического районирования. Дана подробная характеристика основных тектонических оползневых массивов. При этом выявлена их приуроченность к главным тектоническим структурам: выделены 3 зоны тектонических сейсмодислокаций, к которым приурочены наиболее крупные оползневые массивы исследуемой территории

Малышков С.Ю., Гордеев В.Ф., Поливач В.И.. Полевые исследования динамики техногенного оползня.

Приведены результаты оценки динамического изменения состояния техногенного оползня методом регистрации естественного импульсного электромагнитного поля Земли (ЕИЭМПЗ) в условиях горноскладчатых областей с активной геодинамикой Северо-Кавказского региона. Даны рекомендации по настройке регистраторов ЕИЭМПЗ, выделению пространственных аномалий и их интерпретации с целью оценки напряженно-деформированного состояния горных пород.

Музаев И.Д., Харебов К.С., Музаев Н.И. Математическое моделирование сейсмических колебаний плотины и подфундаментных слоев грунтового массива с учетом влияния воды в водохранилище.

Составлена математическая модель совместных сейсмических колебаний высоконапорной плотины, водохранилища и двух слоев массива грунта под основаниями плотины и водохранилища. Модель представляет контактную краевую задачу математической фризики в которой учтены взаимозависимости колебательных процессов в грунтовой толще, в плотине и в водохранилище при распространении гармонической сейсмической волны в рассматриваемой системе. В результате решения поставленной задачи получены расчетные формулы для вычисления относительных амплитуд сейсмических колебаний гребня и основания плотины.

Мусаев В.К. Применение волновой теории сейсмического воздействия для моделирования упругих напряжений в курпсайской плотине с грунтовым основанием при незаполненном водохранилище.

Рассматриваются некоторые вопросы численного моделирования сейсмической безопасности бетонной Курпсайской плотины с грунтовым основанием при волновых воздействиях. Плотина моделируется при заполненном водохранилище. Программный комплекс позволяет решать задачи при нестационарных воздействиях на объекты сложной формы. На основе метода конечных элементов в перемещениях разработаны алгоритм и комплекс программ для решения линейных плоских двумерных задач волновой теории упругости. Проведено сопоставление с результатами смешанного метода конечных элементов. Максимальное растягивающее напряжение возникает в верхней части задней области контура плотины. Упругое контурное напряжение на гранях плотины является почти зеркальным отражением одно другого, то есть антисимметричным.

Усманов А.Х. Техногенные залежи углеводородов на территории г. грозный: геоэкологические проблемы и пути их решения.

Статья посвящена истории и современному состоянию проблемы загрязнения геологической среды и образованию техногенных залежей нефтепродуктов на территории г. Грозный в связи с функционированием нефртяного комплекса. Добыча, переработка, транспортировка и хранение нефти и нефтепродуктов сопряжено с образованием отходов, негативно воздействующих на природную среду. Проведен анализ загрязненности нефттепродуктами грунтов в районе г. Грозный. Рекомендованы мероприятия по реабилитации геологической среды от загрязнения нефтепродуктами.

Чернов Ю.К., Чернов А.Ю. Вероятностные модели сейсмических воздействий для прогнозирования сейсмической опасности в инженерных целях.

Предложены вероятностные модели пиковых ускорений, спектров и других параметров сильных движений, основанные на статистическом анализе большого объема данных по инструментальной регистрации землетрясений. Модели позволяют повысить точность и надежность прогнозных оценок на региональном и локальном уровне за счет более полного учета особенностей потенциально опасных очагов землетрясений и свойств окружающей геологической среды, включая местные грунтовые условия.

Шемпелев А.Г., Чотчаев Х.О., Кухмазов С.У. Данные глубинных геофизических исследований вдоль Чегемского профиля (Центральный блок, Большой Кавказ).

Геофизические наблюдения вдоль Чегемского профиля (перевал Китлод - г. Буденновск) являются продолжением глубинных исследований структуры Большого Кавказа комплексом геофизических характеристик разреза земной коры в крест всей структуры орогена. На основании фрактических материалов МОВ3, МТ3 и гравимагнитных съёмок выделяются отдельные элементы структуры Большого Кавказа, как части Альпийского коллизионного пояса, очевидно возникшей при пологом надвиге с севера земной коры Скифской плиты на консолидированную кору закавказских микроплит.

Яроцкий Г.П. Глыбово-клавишная структура литосферы активной окраины континента на СВ Азии. Корякско-Камчатский регион.

Показана система северо-западных разломов, определивших продольную зональность региональных геоструктур активной окраины Северо-Востока Азии. Они обусловили линейные и гнездовые вулканогены Северо-Западно- и Юго-Восточно-Корякских орогенных поясов и связь с ними рудных районов. Поперечные разломы создают условия субвертикальных движений окраины геоструктур: погружения и воздымания. В килях слоёв прогнутых горизонтов и замках - выгнутых, 
возникают продольно-осевые разломы - зоны максимальных геодинамических напряжений. На их сочленении с глубинными границами разновозрастных морских террейнов образуются вертикальные сейсмогенные колонны с гипоцентрами сильных $(\mathrm{M}>6,6)$ землетрясений Корякского сейсмичного пояса.

Avetisyan A.M., Nikolayev A.V. Interactive computer-creative methods in the processing of seismic information.

The article is devoted to one of the most important trends in modern geophysics - tomography, which is designed to investigate geological objects by studying the features of the passage through them of electromagnetic and elastic seismic waves. To solve seismological problems, the quality of the initial data is important, in addition, when processing seismological information it is necessary to use several models of the medium under the assumption that each of them can induce experimental data of indirect measurements. The choice of solutions for each interpreter can be individual, and can depend on experience, intuition and other circumstances. The paper outlines the problems that arise when solving theoretical problems and practical seismic investigations and ways of overcoming them through modern concepts and approaches.

Гиоргобиани Т.В., Закарая Д.П. Геолого-струк- турное строение Большого Кавказа вдоль Военно-Грузинской дороги.

В статье приведено описание составленного авторами вдоль Военно-Грузинской дороги геолого-структурного разреза, протяженностью более 100 км, пересекающего складчатое сооружение Большого Кавказа. Даны характеристики сложных складчато-разломных структур тектонических зон Большого Кавказа по отдельным участкам Военно-Грузинской дороги, позволяющие получить представление о внутреннем строении этого региона. Приводится краткое описание, рассекающего складчатые структуры юрских и меловых толщ, кливажа осевой плоскости. Рассмотрены диабазовые дайки, секущие складчатость зоны Главного хребта Большого Кавказа. Высказано предположение об их образовании в позднемиоцен-раннеплиоценовое время. Выяснено, что Гвелетский и Дарьяльский гранитоидные массивы находятся во вторичном аллохтонном залегании. Они являются фррагментами пород, оторванных от древнего палеозойского крупного гранитоидного массива. Их современное расположение вызвано субвертикальным протрузивным перемещением и внедрением их в перекрывающие верхнепалеозойские и нижнеюрские толщи. Это происходило в обстановке интенсивного тангенциального сжатия Большого Кавказа в процессе проявления роданской и последующих фаз складчатости.

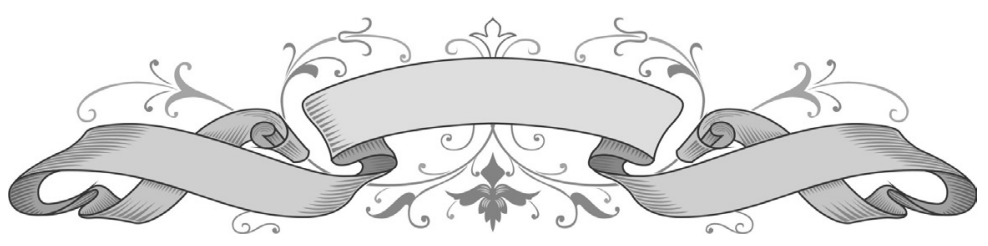




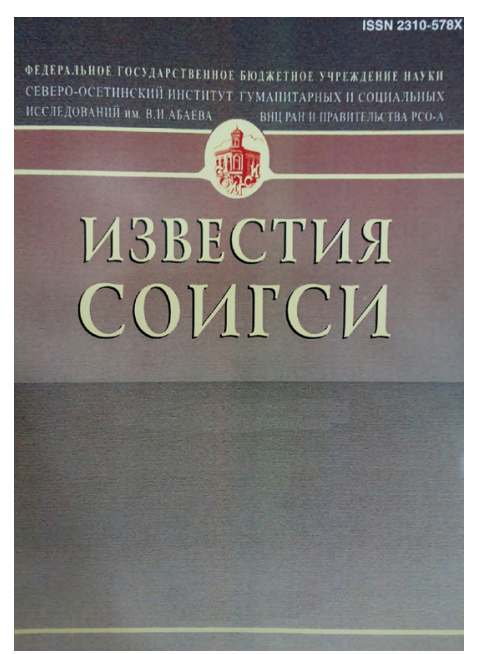

Дарчиев А.В. О военном культе аланов.

В статье рассматривается культ военного божества, занимавший важное место в религиозных представлениях аланов. Сопоставление сведений античных источников с данными фольклора и этнографрии осетин, современных потомков аланов, проясняет некоторые черты этого культа. Давнее предположение Б. Бахраха о том, что бог войны, почитавшийся аланами в виде меча, был также и повелителем загробного мира, находит подтверждение в осетинском эпосе. Нартовский герой Батраз, который считается эпической ипостасью бога войны, выступает и как владыка загробного мира. В пользу этого свидетельствуют и некоторые специфрические элементы осетинской поминальной обрядности (прикосновение ножом ко всей посвящаемой покойному пище, втыкание ножа в могильную насыпь). Легенда о священном мече скифов (resp. аланов), найденном при помощи коровы, трактуется как трансформация мифа о боге войны, рожденном коровой, и о его зооморфном воплощении в образе быка. В пользу такой трактовки свидетельствуют некоторые специфические черты и деяния нартовского Батраза: в детстве его вскармливают коровы, он способен превращаться в быка, по велению Шатаны он схватывается с нартовским стадом бугаев, бодаясь с ними, словно бык. Известная гипотеза о влиянии аланского военного культа на фрормирование западноевропейских легенд об Артуре дополнительно подкрепляется в статье некоторыми данными осетинского нартовского эпоса. К уже известным нартовским аналогиям мотиву артуровских легенд о «мече в камне» приводится еще одна: Батраз вонзает в землю необычное оружие, представляющее собой меч и копье одновременно. Кроме того, в качестве соответствий мотивам о «мече в камне» и «мече из озера» приводятся примеры из ведийской мифологии: ваджра, чудесное оружие грозового божества, пронзает гору/камень, а в некоторых контекстах описывается как лежащая в море. Высказывается предположение, что в аланском военном культе существовали ритуальные танцы с мечами.

Нарожный Е.И. В.Н. Татищев и Екатерина II: Первые шаги в изучении средневековых памятников Северного Кавказа.

В статье рассматривается документ 1768 года с автографом Екатерины Великой, повествующий об анонимном посещении (1742 г.) целого ряда средневековых памятников Северного Кавказа. На основании сведений историка начала XX в. Н.Ф. Катанова, справедливо указавшего на существование в документе трех случаев, когда императрица ведет свое повествование «от муж-

\section{ИЗВЕСТИЯ СОИГСИ}

Выпуск 24(64) 2017 ского лица», в статье проверяется его предположение о том, что эта информация была «списана императрицей» из какого-то источника. Сравнение упоминания золотоордынского Маджара, легенды об атамане А. Шадре и других данных позволяет предположить, что содержащиеся в документе сведения могли быть заимствованы у В.Н. Татищева. Сегодня это мнение подкреплено и находкой почти идентичного текста в «Истории Российской» Татищева. Сопоставление текстов документа императрицы и отрывка из сочинения российского историка вполне объясняет причины повествования Екатериной «от мужского лица». При этом очевидной становится и необходимость дальнейшего (в перспективе) анализа данных о том, когда и по каким причинам посещался Кизляр, Татартуп, «Юлат» и другие памятники региона.

Пигарь С.С. Лидерство у горцев Кавказа в XIX в.: Абхазский вариант.

Возрождение в настоящее время различных элементов традиционной политической культуры кавказских горцев заставляет обратиться к эпохе, когда эта культура существовала в ее оригинальном состоянии - до и в процессе вхождения Кавказа в Россию в XIX в. Одним из важнейших ее аспектов является лидерство, ярко проявлявшееся в абхазском обществе. У кавказских горцев персональный авторитет являлся сочетанием репутации и связей и определял успех и влияние личности. Титул, сословная принадлежность, богатство являлись подчиненными факторами, соответственно, политическая иерархия не совпадала с социальной. Персональные качества и репутация лидера лежали в основе его власти. Власть как таковая воспринималась горцами как одно из свойств личности. Власть лидера основывалась на численности его добровольных приверженцев, которые поддерживали отношения взаимовыгодного сотрудничества со своим лидером. Поскольку личность лидера была неотделима от сообщества его последователей, лидерство было, скорее, френоменом не личностным, а корпоративным. В основе абхазской культуры лежало стремление не подавить социальную активность людей, а регулировать ее таким образом, чтобы рост влияния лидера, его богатства и известности могли бы рассматриваться как достижения его группы. Более того, команда лидера не только поддерживала его, но и существенно ограничивала его амбиции. Традиции самоуправления в горском обществе не допускали политических лидеров к участию в экономической и духовной жизни общества. Эти функции выполняли лидеры особого типа - старейшины, ко- 
торые были ведущей силой в неполитических областях общественной жизни. Они являлись посредниками между субъектами и объектами политических отношений, исполняя роль стороннего наблюдателя, дающего морально-правовую оценку происходящим событиям.

Марзоев И.Т. Род Баевых в истории Осетии (XIX - начало XX в.)

В статье представлено историко-генеалогическое исследование фрамилии Тагаурского общества Северной Осетии Баевых, основанное на архивных источниках и опубликованных материалах. Фамилия Баевых дала Осетии ряд ярких представителей военной интеллигенции, деятелей науки, общественных и политических деятелей. В статье рассмотрены исторические судьбы представителей этой фамилии в XIX - начале XX в.: генерал-лейтенанта Гадо Баева, блестящего финансиста Льва Баева, героя русско-турецкой войны 1877-1878 г. Александра Баева, георгиевского кавалера, участника Дунайской компании Захара Баева, активного члена «Общества распространения образования и технических сведений среди горцев Терской области» Василия Баева, участника Белого движения генерал-майора Павла Баева, ученого-астролога, профессора астрономии Константина Баева, организатора ветеринарной службы в Осетии Петра Баева, первого городского голову Гаппо Баева, офрицера Генерального штаба Дзандара Баева, присяжного поверенного Измаила Баева, доктора математических наук Андрея Баева, известного революционера Чермена Баева и др. Материалы исследования существенно дополняют историю Осетии, способствуют более глубокому и обновленному исследованию генеалогии осетинских фамилий.

Далгат Э.М., Салихова Л.Б. История возникновения городов Дагестана (XX век).

Статья подготовлена в рамках программы фундаментальных научных исследований РАН по теме «Города Дагестана: историко-этнографическое исследование (XIX-XX вв.)» (0209-2015-0001)

Статья посвящена истории возникновения городов Дагестана в XX веке. Отмечено, что 6 из 10 городов Дагестана, а именно Хасавюрт, Дагестанские Огни, Кизилюрт, Каспийск, Избербаш и Южно-Сухокумск приобрели данный статус в советское время. В статье уделено внимание каждому из указанных городов, они рассмотрены со времени их возникновения, показан их рост и развитие период приобретения статуса города. Отмечено, что появлению городов из рабочих поселков способствовало для одних - строительство крупных промышленных предприятий - завода № 182 («Двигательстрой»), стекольного завода «Дагестанские Огни», для других - обнаружение нефти и газа, строительство ГЭС и т.д. Все это благоприятствовало увеличению населения городов, повышению благосостоянию горожан, изменению образа жизни многих дагестанцев, а также развитию транспортной и социально-культурной инфраструктуры городов и республики. Обращено внимание на то, что крупные предприятия, построенные в Дагестане в XX в. и оказавшие непосредственное влияние на развитие и формирование городов, в тоже время заложили основу для кризиса в фуннционировании городов в конце XX начале XXI в.

Цориева И.Т. Кинематограф народов Северного Кавказа в 1960-е - 1980-е ге.: историко-политические аспекты развития.

В статье на основе воспоминаний современников и архивных источников рассматривается история разви- тия кинематографра в республиках Северного Кавказа в 1960-е - 1980-е гг. Подчеркивается, что создание телевизионного документального и игрового кино в регионе во многом было результатом национальной культурной политики. Вместе с тем, отмечается существенное влияние на становление киноискусства практики культурного патернализма, получившей распространение в среде местной политической элиты в изучаемый период, и значительный вклад руководителя Гостелерадио Северо-Осетинской АССР А.Т. Агузарова в создание региональной базы кинопроизводства на Северном Кавказе. Региональное киноискусство развивалось в рамках государственной программы «социального заказа». Деятели кино решали конкретные задачи пропаганды советского образа жизни, воспитания людей в духе преданности социалистическим идеалам, патриотизма и интернационализма. Необходимость соблюдения идеологических, цензурных требований существенно ограничивала свободу творческого поиска, нередко приводила к схематизму, плакатности сюжетов и образов. Но в целом транслируемые северокавказским кинематографом гуманистические идеалы добра, справедливости, мирного сосуществования народов перекликались с настроениями большинства многонационального населения региона и находили отклик в сердцах обычных людей.

Цибиров Г.И. Проблемы истории Осетии и народов Северного Кавказа в трудах А.К. Джанаева.

В статье прослеживается жизненный и творческий путь Акима Казбековича Джанаева - одного из видных представителей поколения осетинской научной интеллигенции, чья творческая биография складывалась в период глубоких общественных трансформаций первой половины XX в. А.К. Джанаев рано проявил интерес к гуманитарному знанию, который со временем превратился в осознанное желание стать профессиональным историком. Этому способствовала и общественная атмосфера 1920-х - 1930-х гг., когда образованная часть общества активно вовлекалась в обсуждение вопросов идеологического обоснования строительства социализма в СССР. Джанаев много лет преподавал в разных учебных заведениях. Но его главным призванием стало занятие наукой. В статье отмечается большой вклад ученого в развитие исторического осетиноведения и кавказоведения. Автор характеризует основные направления научно-исследовательской деятельности Джанаева. Обширность его научных интересов подчеркивает перечень тем, к которым исследователь обращался на протяжении своей долгой жизни в науке. Среди них вопросы фреодального землевладения в Дигории, развития революционного движения и социалистического строительства на Северном Кавказе, проблемы осетинской историографии, археографические и источниковедческие изыскания и т.д. Представлен библиографический список трудов А.К. Джанаева, в котором значится 84 названия, включающих монографоии, статьи, а также сборники научных статей и документов, в подготовке которых участвовал исследователь.

Цаллагова И.Н. Семантическая и денотативная характеристика соматической лексики Дигорского варианта осетинского языка.

Соматическая лексика является одной из универсальных групп лексики в любом языке. Ввиду этого именно данная группа слов является одной из самых распространенных объектов исследований сравнительно-исторического, структурно-сопоставительного и лингвокультурологического характера. Как в отечественных, 
так и зарубежных лингвистических исследованиях, как правило, эту лексику выделяют первой в лексико-тематической системе любого языка. Настоящая статья посвящена исследованию соматической лексики дигорского варианта осетинского языка, так как данная проблематика в осетинском языкознании недостаточно изучена. В статье дается понятие соматической лексики, анализируется место соматической лексики в лексической системе языка. Рассмотрены различные классификации соматизмов. Наиболее приемлемой для соматической лексики дигорского варианта осетинского языка признана классификация, основанная на их функциональных признаках и характере объекта номинации, а также на противопоставлении «внешнее/внутреннее». В исследовании выявлен состав соматической лексики дигорского варианта осетинского языка, который проанализирован и систематизирован. Дана семантическая и денотативная характеристика дигорских соматизмов. Выявлено, что для дигорских соматизмов характерна сложная система переносных значений и повышенная продуктивность в словообразовании и образовании идиоматических сочетаний.

Сатцаев Э.Б. Эволюция рода в иранских языках.

В статье исследуются вопросы эволюции категории рода в иранских языках. Особое внимание отводится исследованию западно- и восточноиранских языков в исторической перспективе. На основе широкого спектра лингвистических данных подробно описаны и охарактеризованы как общие черты, так и особенности грамматики языков иранской группы. Последняя входит в индоевропейскую языковую семью, представленную в настоящее время на обширном географическом пространстве. Наиболее многочисленной ветвью данной семьи является индоиранская, включающая в себя индоарийские и иранские языки, обособление которых началось с миграций предков современных индоариев в северо-западную Индию. История ираноязычных племен и народностей, территория расселения которых в прошлом простиралась от берегов Черного моря на западе до границ Китая на востоке и от Южного Урала на севере до берегов Персидского залива и Индии на юге, охватывает огромный временной промежуток - от II тыс. до н.э. вплоть до наших дней. Диалекты многих из них еще на рубеже двух эр сохраняли значительную степень единства, унаследованного от общего древнеиранского языка-основы, близкого к авестийскому.

Калабекова Л.Т. Смысловая доминанта глагольного вида в языках разной типологической модели.

В статье показывается, что в качестве ключевого семантического признака категории вида в языках разной типологической отнесенности целесообразно рассматривать абстрагированное значение целостности/процессности глагольного действия. Именно этот признак дает основание для сопоставления аспектологических возможностей разносистемных языков (в нашем случае фрранцузского, русского, осетинского). Сравнительнотипологические разыскания, проводимые как в рамках близкородственных языков, так и на уровне языков неродственных, вскрывают тот неопровержимый фракт, что в основе всех расхождений (лексической, семантической и синтаксической природы) лежат в первую очередь системные особенности любого отдельно взятого естественного языка. Иллюстрацией сказанному могут служить некоторые расхождения между французской, русской и осетинской лингвосистемами, проявляющиеся в способности упомянутых языковых культур выражать разнообразные аспектуальные смыслы. Для типологических исследований аспектологического порядка немаловажным становится выявление общих параметров, позволяющих соотносить содержательную сторону исследуемых систем в рамках обозначенной проблематики. Так, в частности, представляется целесообразным рассматривать абстрагированное значение целостности/процессности действия, в качестве основного семантического признака глагольного вида в языках разной структурной модели (в нашем случае: французском, русском, осетинском). При этом в пределах упомянутой корреляции обнаруживаются более частные семантические смыслы, а именно: длительность/недлительность, законченность/незаконченность процесса. Последний из обозначенных семантических признаков способен включать в свою активность отношение действия к результату, что представляется вполне естественным, так как о результативности мы судим лишь в том случае, если действие завершено. Незавершенное действие не может достичь какого бы то ни было результата. Приведенные значимости видового порядка возникают в речевом потоке вследствие взаимодействия множества средств различных языковых уровней: лексического значения глагольной лексемы в совокупности со значением ее грамматической фрормы и синтаксического окружения. Иначе говоря, в пределах функционально-семантической категории (ФСК) аспектуальности происходит распределение семантических признаков на основной категориальный и периферийные. Регулярность выражения последних, как бы суживается от одного аспектуального признака к другому. Так, например, если длительность свойственна практически любому процессному действию, то далеко не всякое целостное действие является результативным.

Дзапарова Е.Б. Созырыко Бритаев как практик и теоретик художественного перевода в осетинской литературе.

В статье рассматривается переводческое наследие Созырыко Бритаева, оценивается вклад переводчика в теорию и практику художественного перевода. Автором анализируются переводы С. Бритаева, выявляются способы воссоздания в переводном тексте формы и содержания оригинала. Анализируя рассказ Л.Н. Толстого «После бала» в оригинале и в переводе С. Бритаева, исследователь рассматривает способы отображения в переводном тексте основного структурообразующего элемента произведения - контраста. Установлено, что переводчику С. Бритаеву удалось воспроизвести стиль повествования, систему художественных образов оригинала, архитектонику произведения. Прослежена передача на языке перевода и образных единиц оригинала (метафрор, эпитетов). Переводчик в основном воспроизводит данные единицы перевода в оригинальной творческой манере русского писателя. Замена отдельных метафорических структур эквивалентами переводящего языка позволила Бритаеву сохранить структуру тропа, но привела к утрате его эстетической функции. Перевод некоторых эпитетов требовал отхода от словарных соответствий и нахождения эквивалентов по смыслу. eer.

Бритаева А.Б. Художественный мир С.А. Брита-

В статье на материале произведений С.А. Бритаева, осетинского писателя, сказочника, переводчика, публициста, исследуются основные тенденции развития осе- 
тинской детской литературы середины XX в. как подсистемы осетинской художественной словесности в целом. Дан комплексный анализ авторских сказок писателя, специфика, «особая художественность» которых заключается в их синтетической природе; через призму диалога индивидуально-авторского начала и традиционных сказочных жанрообразующих элементов в различных аспектах (жанровый синтез, система образов, стилистические особенности, авторская позиция) раскрывается художественный мир писателя. С опорой на архивные источники впервые введены в научный оборот произведения малой прозы автора, в том числе ряд неопубликованных рассказов. На основе исследования своеобразия творчества автора прослежены основные тенденции и характерные черты развития осетинской детской литературы указанного периода, как то: синтез фольклорных средств с собственно литературными (описания, детализация действия, психологизм, пластичность изображения), тенденция к переходу от фольклорных типов-обобщений к созданию индивидуализированных характеров; от народно-сказовой фоомы повествования и традиционных способов передачи коллективной точки зрения на мир к усилению творческого самовыражения, своеобразию проявления авторской позиции.

Мамиева И.В. Современная осетинская поэзия: жизнь после.

В статье представлен обзор осетинской поэзии перестроечных лет (1985-1991 гг.) и постсоветского периода (1992-2000-е гг.). В ней в общих чертах воспроизводится специфичность состояния художественного сознания осетин в границах вышеозначенных хронологических срезов. Делается попытка на фоне радикальных политико-экономических преобразований, духовно-ценностных сдвигов в обществе проследить эстетико-смысловую иерархию поэзии указанных лет обрисовать неоднозначную атмоссреру идеологических размежеваний в литературной среде. Наряду с проблемно-тематическими приоритетами и узловыми тенденциями творчества уже состоявшихся мастеров слова особое внимание уделяется пространству поэтического мира, формируемого новой генерацией стихотворцев. Не претендуя на исчерпывающую полноту, автор показывает абрисы поэтов, чьи творческие дебюты в основном пришлись на постперестроечное время, а потому несут в себе элементы несколько иного восприятия жизни и своего места в ней, демонстрируют свою логику «притяжения-отталкивания» при соприкосновении с национальной традицией и с опытом мировых духовно-ментальных практик. Статья предназначена для специалистов по осетинской фрилологии, а также широкого круга читателей, интересующихся поэтической картой Осетии.
Дзалаева К.Р. К истории русского театра во Владикавказе.

Исследование выполнено в рамках Программы фундаментальных научных исследований Президиума РАН «Историческая память и российская идентичность»

Представленные документы характеризуют причины и условия возникновения Русского драматического театра во Владикавказе во второй половине XIX в. Материалы фондов Центрального государственного архива РСО-А и Научного архива СОИГСИ, подтвержденные сведениями театральной хроники местной периодической печати, раскрывают неизвестные страницы истории Русского театра, связанные с его возникновением, финансово-организационными и кадровыми вопросами, строительством и архитектурным обликом театрального здания в разные периоды времени. Особое внимание уделяется роли Русского театра в формировании городской общественно-культурной среды Северного Кавказа.

Хадикова А.Х. О мифологических истоках и ареальных связях осетинской Нартиады.

(Рецензия на монографию: Чибиров Л.А. Осетинская Нартиада. Мифологические истоки и ареальные связи. Владикавказ: Ир, 2016. 464 с.)

В предлагаемой рецензии на монографрию профессора Л.А. Чибирова «Осетинская Нартиада. Мифологические истоки и ареальные связи» подчеркивается особенная актуальность, своевременность и многоаспектное значение этого труда - научное, просветительское, методологическое. В условиях, когда в нартоведении стали слишком заметны тенденции отстаивания узконациональных интересов, рецензируемый труд является примером возвращения к принципам научного анализа и объективного историзма. Монография содержит целенаправленное и разностороннее исследование нартовского эпоса, в различных вариантах бытующего у многих народов Северного Кавказа, его генезиса, условий формирования и путей распространения. Большую ценность представляют сопоставительные параллели, скрупулезно отслеживаемые автором на базе обширного и оригинального материала: от нартовского эпоса к скифам, а через них к европейским, иранским и индоиранским древностям, эпическому пространству Евразии. Системному анализу подвергаются кавказские варианты эпоса, а также динамично развивающиеся версии о центрах формирования ядра эпоса. Л.А. Чибиров представляет читателю научно аргументированный вывод о бесперспективности дискуссий об авторстве эпоса и о приемлемости единственной версии — научной.

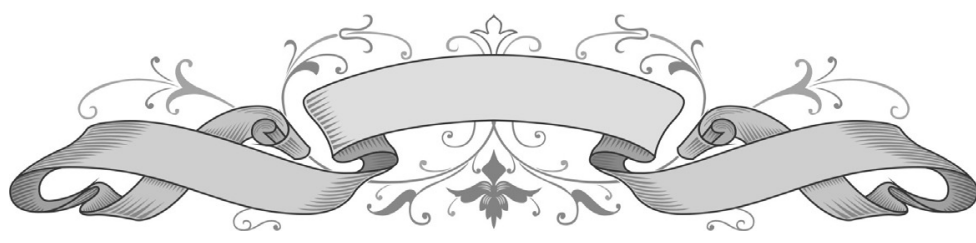

